sciendo Порівняльна професійна педагогіка 8(3)/2018 Comparative Professional Pedagogy 8(3)/2018

DOI: $10.2478 /$ rpp-2018-0035

$\mathrm{PhD}$ in Pedagogy, Associate Professor, OLESIA SADOVETS

Khmelnytskyi National University

Address: 11 Instytutska St., Khmelnytskyi, 29016, Ukraine

E-mail: lesyasadovets@gmail.com

Doctor of Pedagogy, Professor, NATALYA BIDYUK

Khmelnytskyi National University

Address: 11 Instytutska St., Khmelnytskyi, 29016, Ukraine

E-mail: tretko@ic.km.ua

\title{
STANDARDS OF FOREIGN LANGUAGE TEACHERS' PROFESSIONAL TRAINING: PROSPECTS AND FOREIGN EXPERIENCE
}

\begin{abstract}
The article deals with an urgent issue of necessity to enhance professional training of future foreign language teachers. It has been substantiated that the only way to assess its quality is to use a set of professional standards. Theoretical substantiation of the standards elaborated by TESOL, as well as their step-by-step process of elaboration, have been studied. These standards served as a model for developing standards of foreign language teachers' professional training in other countries. On their basis the standards of foreign language teachers' professional training, as well as indicators of teachers' performance for each of them, have been formulated as a role model for other countries which pay special attention to foreign language teachers' training. The main difficulties of the standards implementation have been defined, as well as their possible solutions. One of the most urgent issues raised in the article is the necessity to elaborate a detailed system for assessing teachers' correspondence to the standards and to adjust the existing training programs to them. Conclusions about productivity and efficiency of the conducted research can only be made after the standards approbation throughout the complete foreign language teachers' training program that is 4-6 years (depending on the degree-Bachelor or Master). Still, at this stage of our research it is quite clear that one of the possible solutions to the problem of the necessity to elaborate a detailed system for assessing teachers' correspondence to the standards and to adjust the existing training programs to them is involvement of stakeholders of different levels to elaboration of the standards (from future teachers to educational authorities). The practical value of the presented material is that it can be used by other countries for elaborating their own national standards.

Keywords: higher education, English education, comparative education, educational evaluation/assessment, foreign language teachers, professional standards, professional training.

\section{INTRODUCTION}

Globalization and internationalization of society, as well as an increasing demand for specialists fluent in foreign languages, put forward greater demands on professional training of foreign language teachers. This situation is especially urgent in developing countries, as the proper level of foreign language knowledge provides new opportunities for education and employment. Thus, appropriate training of teachers who are to provide
\end{abstract}


sciendo Порівняльна професійна педагогіка 8(3)/2018

Comparative Professional Pedagogy 8(3)/2018

qualitative process of foreign language teaching in schools is one of the top priorities. These teachers are expected to undergo constant professional development, correspond to modern demands (e.g., the ongoing technical progress that enriches the language with new notions) and have the ability to use technologies to enhance learning. Teachers must be flexible, take into consideration multi-cultural and multi-language approaches, diversity of the society, in which foreign language communication takes place.

Foreign language teachers must develop professionally and be competent. To correspond to these demands there must be compiled a list of their competencies which will serve as indicators of their competence in general. Evaluation of competencies is impossible without clearly defined and approved standards. They must determine theoretical and practical knowledge, necessary for teachers of foreign languages, their educational and social duties (e.g., to introduce the culture of the target language to students, to teach them to respect it). At the same time, governing bodies of schools must provide qualitative training programs, presupposing theoretical and practical knowledge of future teachers, formation of their cultural values, as well as special and general competence.

\section{THEORETICAL FRAMEWORK AND RESEARCH METHODS}

In Ukraine, particular attention is paid to foreign language teachers' training with consideration of all the above mentioned aspects. A lot of home scientists dedicate their works to issues of future foreign language teachers' professional training and competence formation. V. Barkasi (2004) and I. Bihych (2004) study competence of foreign language teachers, O. Kotenko (2011) pays attention to formation of professional qualities of foreign language teachers, S. Nikolayeva (2010) has worked out the concept of foreign language teachers' training, and others. But still no standards have been developed in Ukraine yet. Some work has been carried out by the British Council in Ukraine within the project "Common European Framework of Reference for Languages: Learning, Teaching, Assessment" (2001). Thus, there is a great demand for elaboration of standards of foreign language teachers' professional training. Therefore, there arises a necessity to follow some foreign experience of developing such standards. We have studied and analyzed a great deal of works dedicated to professional training and performance of teachers, especially concerning: opportunities for teachers' professional development (K. Burke (2011), T. Farrell (2014)), professional education of teachers (L. Darling-Hammond (2017), D. Flink (2003)), teacher professionalism (A. Hargreaves (2003)), professional teaching standards (Kuhlman (2013)), competence and performance in language teaching (J. Richards (2017)), and others. International organizations, such as Council of Europe, International Board of Standards for Training, Performance and Instruction - IBSTPI, National Council for Accreditation of Teacher Education, TESOL International Association, have been conducting research in this field and have an extensive experience in developing the standards of future teachers' training.

Having studied the publications and research papers of the above mentioned scientists, documents and materials of international organizations we have carried out our own research concerning prospects of elaborating the standards of foreign language teachers' professional training in Ukraine. For this we have used a range of general scientific methods (including study and analysis of reference, scientific educational print and on-line sources), as well as comparative method, systematization and generalization. To validate and implement the results of our theoretical developments we have used a questionnaire method, method of statistical analysis and processing of the workgroup's findings and conclusions. 
sciendo Порівняльна професійна педагогіка 8(3)/2018 Comparative Professional Pedagogy 8(3)/2018

\section{RESULTS}

In the result of theoretical and comparative analysis of the material concerning standards of foreign language teachers' professional training, worked out by previously mentioned organizations and professional associations, it has been defined that professional standards of foreign language teaching by TESOL (Teaching English to Speakers of Other Languages Association) - TESOL P-12 Professional Teaching Standards - are the most appropriate for elaboration of the respective standards in Ukraine.

Such a decision has been made due to the fact that the Association not just formulated the standards but worked out the key points for elaborating corresponding standards by other countries. They stipulate the possibility of their usage in different contexts with consideration of the educational policy of a target country. Key points of TESOL standards presuppose all the necessary parameters for working out (adaptation) of the standards that correspond to demands of the global society, take into account national and regional educational policy, stipulate active participation of Ministry of Education, professional and non-governmental organizations. They contain theoretical basis and organizational formats for the standards, indicators of future foreign language teachers' performance, step-by-step process of the standards' working out, methods of their evaluation/assessment, describe the experience of the standards' implementation in developing countries (National Council for Accreditation of Teacher Education, 2010).

Before starting the process of the standards elaboration in Ukraine, we have studied and analyzed theoretical and organizational bases for the fulfillment of this process. It has been determined that to elaborate the standards the following conditions are necessary:

1. Theoretical and conceptual basis (theoretical framework, the aim and tasks of the standards). The concept of foreign languages teachers' professional training standards must encompass teacher's professionalism, which is ensured by four main factors: a) language knowledge; b) culture and its influence onto learners; c) learning process that is planned, implemented and assessed on the basis of foreign language teaching standards and presupposes effective use of resources and technologies; d) assessment of future teachers' language knowledge (TESOL International Association, 2010; TESOL International Association, 2013; TESOL International Association, 2017).

2. Appropriately substantiated organizational formats for the standards. In general, TESOL outlines two approaches to standards elaboration: field and principle-based (the former is more widely spread). The difference between them can be explained as the difference between specific and abstract. At the same time, principle-based approach is more conceptual, while field approach is more performance-oriented (Liyanage et al., 2015)

Principles are a theoretical background for the standards. Scientists A. Mahboob and N. Tilakaratna (2012) define the following principles for standards elaboration: collegiality; appropriateness; scientific substantiation; correspondence to educational programs, curricula and educational policy; transparency; efficiency (Mahboob \& Tilakaratna, 2012).

Field standards must comprise teaching performance indicators which testify to the efficiency of teachers' training process. On the basis of TESOL research (2010), there have been defined five main knowledge fields that must be included into foreign language teachers' training: language (main field), culture (main field), learning (applied field), assessment (applied field), professionalism (combination of all fields) (TESOL International Association, 2010; TESOL International Association, 2017).

The Council for the Accreditation of Educator Preparation (CAEP) has outlined four knowledge fields for which standards must be worked out: knowledge of an academic 
sciendo Порівняльна професійна педагогіка 8(3)/2018

Comparative Professional Pedagogy 8(3)/2018

discipline, pedagogical knowledge, educational environment knowledge and professional knowledge (National Council for Accreditation of Teacher Education, 2010). European Council has worked out Common European Framework of Reference for Languages: Learning, Teaching, Assessment, in which field standards stipulate the structure of teacher training program, their knowledge and abilities, strategies and skills, and values (Council of Europe, 2001).

National Foreign Language Teaching Association of the USA in cooperation with TESOL has defined the most widely spread knowledge fields for foreign language teachers which must have been compassed by their professional performance: language knowledge; values and attitudes; planning, implementation and assessment of learning; critical thinking; research; culture knowledge; evaluation of teaching and learning; extracurricular activities.

3. Standards: every standard (either a specific or a general one) has to outline an aspect of teachers' knowledge or abilities according to every principle or criterion. Standards, to some extent, can serve as evaluation criteria (TESOL International Association, 2013) or a set of aims that must be reached by future foreign language teachers. Standards are an indicator of consistence and stability of fulfilling everything that is expected of teachers. Tests and other types of assessment are worked out to check teachers' correspondence to the standards (Darling-Hammond, 2017).

In general, three types of standards peculiar to foreign language teachers' training can be singled out: subject-based, pedagogical and performance-based. Subject-based standards assess teachers' subject knowledge. They are of two types: declarative (teachers' knowledge of concepts and facts) and procedural (teaching knowledge) (TESOL International Association, 2010; TESOL International Association, 2017).

Pedagogical standards are concentrated on teaching and learning process (curricula and training programs), effective teaching strategies (planning, teaching itself, analysis, assessment), diversity of students and educational approaches, influence of culture on learning and teaching, teachers' knowledge concerning psychological peculiarities of learning, teachers' knowledge of standardized learning and assessment.

Performance-based standards demonstrate the level of professional teaching correspondence to the standards, criteria and indicators of this correspondence; characterize the level of teachers' work; assess learning activities (Seufert et al., 2005).

4. Indicators of teachers' performance. For each standard there must be worked out indicators of teachers' professional performance which serve as criteria of their correspondence to the standards. For instance, a standard of learning planning may have performance indicators for four language skills (listening, speaking, reading, writing). At the same time, every standard must contain a scale for assessment of performance according to definite levels (e.g., in TESOLP-12 Professional Teaching Standards these levels are called as "approaches the standard", "corresponds to the standard", "exceeds the standard") (Fenner \& Kuhlman, 2012).

5. Application of the standards. It is necessary to define differences between a standardized training program and a non-standardized one. The latter may have some or no general aim or theoretical basis, academic disciplines may have no connection at all, be taught by different chairs or faculties. A standardized program has a definite aim, conceptual basis, general plan and logically connects all the disciplines. Meanwhile, constant relation of teachers within this program is not just desirable but obligatory. Disciplines are interrelated. For instance, an introductory course of linguistics provides a basis for structuring lessons in lexicology, etc. At the same time, teachers are free to use the content and methods of teaching. Some can use a method of work in small groups, whereas others may prefer 
practical work. Thus, they use their own individual teaching method aimed at fulfilling one goal - correspondence to the standards within a commonly accepted theoretical framework. More clearly the difference between standardized and non-standardized foreign language teachers' training programs can be presented in Table 1, which was made partially on the basis of the research conducted by N. Kuhlman (Kuhlman, 2010).

Table 1

Difference between standardized and non-standardized foreign language teachers' training programs

\begin{tabular}{|l|l|}
\hline Characteristics of standardized programs & $\begin{array}{c}\text { Characteristics of non-standardized programs } \\
\text { (based on separate disciplines) }\end{array}$ \\
\hline $\begin{array}{l}\text { General plan, macro level, "holistic } \\
\text { approach". }\end{array}$ & $\begin{array}{l}\text { Microlevel, inability to notice connections or their } \\
\text { Standards are developed with consideration } \\
\text { of different academic disciplines which } \\
\text { can be interconnected. } \\
\begin{array}{l}\text { Flexibility in reaching aims, thorough } \\
\text { planning. }\end{array}\end{array}$ \\
$\begin{array}{l}\text { Integrative assessment, } \\
\text { different assessment methods }\end{array}$ & $\begin{array}{l}\text { Higher level of autonomy in formulating aims } \\
\text { and program elaboration. } \\
\text { Assessment within a separate academic discipline }\end{array}$ \\
\hline
\end{tabular}

6. Evaluation of future foreign language teachers' work and its correspondence to the standards (e.g., with the help of a portfolio) to check the extent to which teachers correspond to worked out criteria and to find out if they have learned something new. For evaluation it is not enough to use tests because they reflect knowledge in a definite period of time, that is, they are a kind of summarizing or general assessment. And as tests mainly presuppose multiple choice, a student has only one task - to guess, recognize or recall the right answer, which does not provide opportunity to assess their actual knowledge and skills. Thus, on the basis of tests, teachers cannot make a conclusion whether students can use their knowledge in practice. Besides, tests are very subjective, as they reflect only the material, which, to a test compiler's mind, is important. Because of this, it is much more reasonable to evaluate teachers' performance by key tasks, such as lesson planning or a portfolio, which provide a wide range of assessment opportunities. Parts of a portfolio can include a video of a teacher's lesson, their educational projects, results of some international language knowledge exam (TESOL International Association, 2013). Portfolio provides an opportunity to assess competence level and correspondence of future teachers' performance to the standards. But, at the same time, portfolio must be coordinated with the standards used for teachers' training program. Besides, there must be elaborated a system of portfolio evaluation according to some criteria, which provide the consistence of its quality assessment. To determine the level of a future foreign language teacher's readiness to licensed work there must be used thoroughly prepared descriptions of what "corresponds to the standard", "approaches the standard" and "exceeds the standard" mean (Fenner \& Kuhlman, 2012). These criteria can be used even when portfolio is not a part of teachers' evaluation process, e.g., to define whether every indicator of the individual performance mentioned in the standards is met (Burke, 2011).

It is important to mention that criteria can be holistic, analytical and single. Holistic criteria estimate general performance with one mark. Analytical ones define key characteristics 
sciendo Порівняльна професійна педагогіка 8(3)/2018

Comparative Professional Pedagogy 8(3)/2018

or divide a holistic mark (score) into key parts, similar to an essay that can be divided into an introduction, main part and conclusion (TESOL International Association, 2017). Every part in itself forms some mark. Single criteria estimate work by one criterion, e.g., assessing an essay by its being persuasive or not. Holistic criteria, as a rule, are used as summarizing assessment, whereas analytical and single criteria are used as current assessment (during the whole academic discipline or academic year) (Arter \& McTighe, 2001).

Effective criteria demand the description of the task (what future teachers have to do), presuppose some assessment scale and substantiation of tasks appropriateness (what knowledge and skills have to be formed) (Stevens\&Levi, 2005). Thoroughly worked out criteria are clearly formulated, consistent, detailed, and differentiated.

The use of criteria is an excellent means of providing a feedback between a lecturer and a future teacher (a student) as they demonstrate their promotion in correspondence to the standards. Criteria provide consistence and let students know how they are assessed, and to teachers they give useful information for organization of learning. But despite the diligence of standards elaboration, it is important to keep in mind that they are subjective.

7. While elaborating standards it is necessary to compile a dictionary of terms that must comprise all definitions and concepts for their clear interpretation and usage (National Council for Accreditation of Teacher Education, 2010).

All these elements are a basis for standards elaboration. But it is necessary to keep in mind that they must be open (to be extended and upgraded), dynamic (to be easily changed in the result of their approbation), understandable (concerning their content and formulation) (Council of Europe, 2001; Fenner \& Kuhlman, 2012). Special attention should be given to teacher's level of language knowledge. For this a special test should be used (e.g., international placement tests, which must be of advanced/proficient level for the fifth year students -TOEFL, PET, CPELT, IELTS, PTE Academic). To define the level of language knowledge, a written test, as well as an interview, video demonstration of teaching process, portfolio and other assessment forms can be used (Kuhlman \& Kneževič, 2013).

Having studied all these bases for elaboration of the standards of foreign language teachers' professional training, one can have a clear understanding of everything that must be taken into account while working out the standards. The next stage of our research was to study TESOL step-by-step process of creating the standards themselves - finding the participants of the workgroup, defining the quantity of them, duration of the project, and kinds of support (financial, administrative). It was agreed that the workgroup has to prepare a draft of the standards and submit them for consideration of other stakeholders for review and feedback. This workgroup must comprise only people who have knowledge and skills in all the key branches of a foreign language (in our case- English): language itself, culture, teaching methods, assessment, and professional development. The participants of the group must be a unified team, flexible, open, polite, communicative, non-conflicting, have adequate perception of remarks and critic. It must comprise different stakeholders (teachers, lecturers, future teachers, administrative bodies of educational establishments, representatives of Ministry of Education). The group has to appoint a head and a secretary; clearly define responsibilities and duties of every participant to have productive work of the whole group.

To elaborate the standards of foreign language teachers' professional training in Ukraine we have involved 20 English language lecturers of English Language Practice and Teaching Methods Chair (International Relations Faculty of Khmenlnytskyi National University) who provide training of English language teachers for secondary school; the Chair's Head; the Dean of International Relations Faculty; 4 fifth year students of "Secondary 
Education. English Language and Literature" specialty, and 4 teachers of English from comprehensive schools of Khmelnytskyi city. The result of the workgroup activities was supposed to be a draft of the standards which had to be submitted for consideration of other chairs of the university and the Academy of Liberal Arts in Khmelnytskyi city.

Before the work group started its activities we made sure that teachers were aware of what they were doing, had motivation to reach one single aim and a strategic plan, were consistent and well-coordinated, understood the essence and advantages of standardized education, had support of their initiative from the governing bodies of the educational establishment and other stakeholders, who were ready to help the workgroup with the approbation of their work results within the university (namely, in "Secondary Education. English Language and Literature" specialty).

At the beginning of the work the participants of the workgroup had to fill in the form, which primary aim was to define whether the views of the workgroup participants coincided with those presented in the concept of TESOL standards and whether the latter could be used in the context of educational policy of Ukraine. The last question was aimed at comparing aspects of foreign language teachers' professional training stipulated by the standards, formulated by the participants of the workgroup, with the respective aspects stipulated by TESOL (Table 2).

Table 2

Questionnaire for the participants of the workgroup aimed at elaboration of the standards offoreign language teachers' professional training

\begin{tabular}{|l|l|}
\hline \multicolumn{1}{|c|}{ Questions } & Answers with comments \\
\hline $\begin{array}{l}\text { 1. What must the basis for the standards comprise } \\
\text { and what do you expect to reach in the result of their } \\
\text { elaboration? }\end{array}$ & \\
\hline $\begin{array}{l}\text { 2. How can standards be used in the context } \\
\text { of your work with students? }\end{array}$ & \\
\hline 3. How can effectiveness of the standards be assessed? & \\
\hline $\begin{array}{l}\text { 4. Which approach (conceptual, e.g.,principle-based) } \\
\text { or concrete (practical, field) is it better to use while } \\
\text { elaborating the standards? }\end{array}$ & \\
\hline $\begin{array}{l}\text { 5. What aspects of future foreign language teachers' } \\
\text { professional performance should be included into the } \\
\text { standards? }\end{array}$ & \\
\hline
\end{tabular}

Conclusions of the workgroup concerning aspects of foreign language teachers' professional training that should be stipulated in the standards are presented in Fig. 1 (in percentage correlation).

Having studied the aspects, singled out by the participants of the workgroup, we have determined that they almost coincided with those that were made the basis of TESOL standards (Table 3 ).

It should be mentioned that aspects of teachers' professional performance, singled out by the workgroup, namely, increase of motivation and self-motivation, extracurricular activity, interdisciplinary teaching, and professional cooperation, are stipulated by one or another performance indicator in TESOL standards. 
sciendo Порівняльна професійна педагогіка 8(3)/2018 Comparative Professional Pedagogy 8(3)/2018

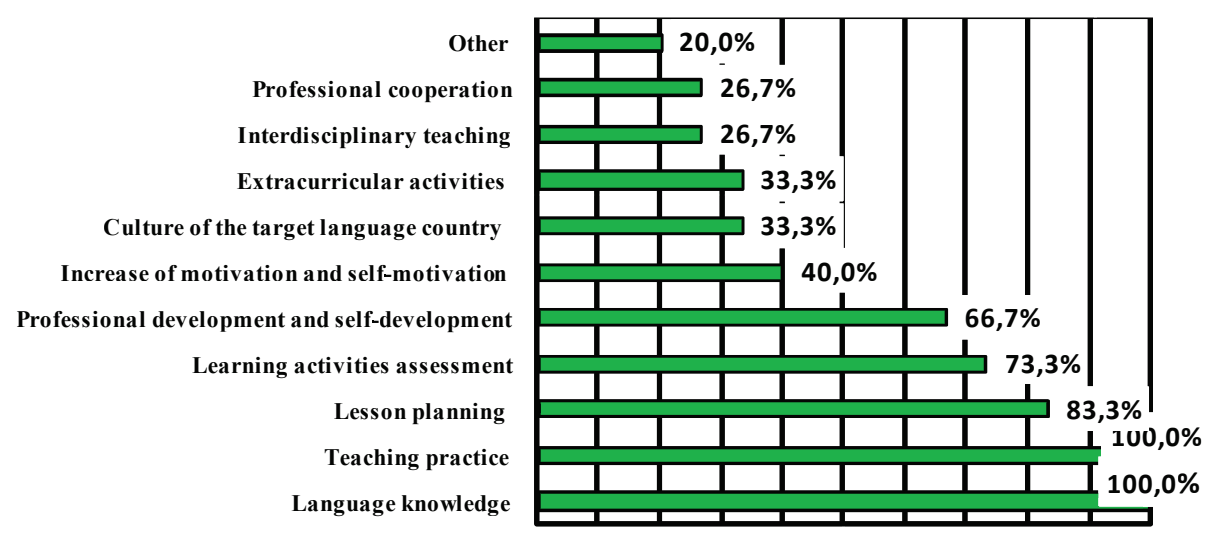

0\% $10 \%$ 20\% 30\% 40\% 50\% 60\% 70\% 80\% 90\%100\%

Fig. 1. Conclusions of the workgroup concerning aspects of foreign language teachers' professional training that should be stipulated in the standards

Table 3

Correlationofaspectsof foreign language teachers' professional performance (in TESOL standards and those, singled out by the workgroup)

\begin{tabular}{|l|l|}
\hline \multicolumn{1}{|c|}{$\begin{array}{c}\text { Professional performance aspects, } \\
\text { stipulated by TESOL standards }\end{array}$} & \multicolumn{1}{c|}{$\begin{array}{c}\text { Professional performance aspects, } \\
\text { stipulated by the workgroup }\end{array}$} \\
\hline $\begin{array}{l}\text { Language. } \\
\begin{array}{l}\text { Culture. } \\
\text { Planning, implementation and control } \\
\text { of the learning process. }\end{array}\end{array}$ & $\begin{array}{l}\text { Language knowledge. } \\
\text { Target country's culture. } \\
\text { Assessment. } \\
\text { Professionalism }\end{array}$ \\
\hline
\end{tabular}

Thus, we have made a conclusion about possibility of using TESOL standards for elaborating our own standards corresponding to the Ukrainian educational environment. After all the participants of the workgroup have studied TESOL standards, a questionnaire was conducted. According to it, 24 participants out of 30 stated that TESOL standards could be used as a basis for working out Ukrainian standards, 6 participants claimed that they could be partially used being adapted to the context of the Ukrainian educational system. 26 participants preferred field approach to standards elaboration, and 4 participants favored the conceptual one. At the same time, 17 participants mentioned that while working out Ukrainian standards the fact that TESOL standards are worked out for native speakersteachers should be taken into account. In Figure 2, the participants' views as to what should be taken into consideration while developing standards on the basis of TESOL standards are shown in percentage correlation (as the result of the conducted questionnaire).

Then, the very work on the development of foreign language teachers' professional training standards has started. It consisted of the following stages:

1. Determining the aim, appropriateness and theoretical framework of this process. 
2. Defining the format/approach to the standards. In the result of the questionnaire, $80 \%$ of teachers chose field approach, according to which standards and indicators of performance are developed for each branch of knowledge.

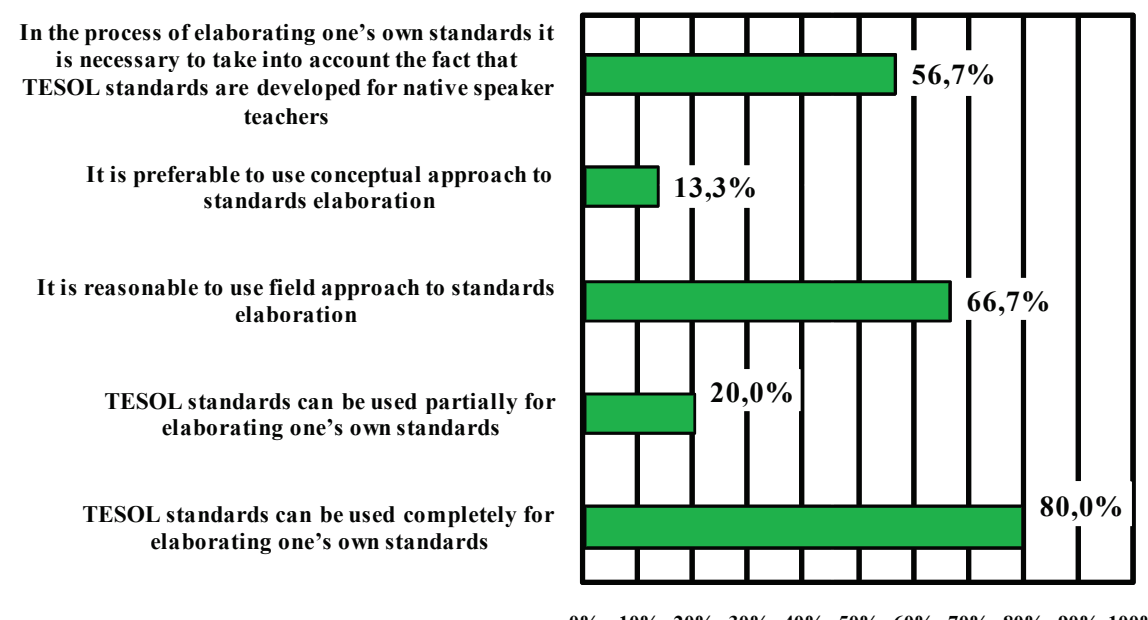

Fig. 2. Results of the workgroup questionnaire about possibilities of using TESOL standards for working out Ukrainian standards

3. Establishing short-term aims (determining fields for formulating standards and defining the standards themselves), long-term aims (elaborating performance indicators for each standard, their approbation on students of "Secondary Education. English Language and Literature" specialty), and deadlines for their fulfillment (3 months - for short-term aims and 5 years - for long-term aims). workgroup.

4. Thorough study and analysis of TESOL standards by the participants of the

5. Elaboration of Ukrainian standards in subgroups to make a draft variant of the standards with the use of respective TESOL standards as a model.

5. Discussion of the draft standards by the whole workgroup and finding out if they correspond to our educational environment and what kind of standards they belong to (subject-based, pedagogical or performance-based).

6. Elaboration of performance indicators for each standard (after their being approved by the whole workgroup).

7. Discussion of performance indicators and elaboration of criteria for each of them. It was agreed by the group that for the Ukrainian standards it was enough to work out a "corresponds to the standard" criterion without TESOL criteria "approaches the standard" and "exceeds the standard".

Step-by-step process of the workgroup activity aimed at developing the standards is represented in Table 4. 
Stages of the standards elaboration and their fulfillment by the workgroup

\begin{tabular}{|l|l|}
\hline \multicolumn{1}{|c|}{ Stage } & \multicolumn{1}{|c|}{ Fulfillment } \\
\hline $\begin{array}{l}\text { Aim and theoretical substantiation. } \\
\text { Organizational work } \\
\text { (deadlines, participants, stakeholders, duties distribution) }\end{array}$ & Discussion within the whole workgroup \\
\hline $\begin{array}{l}\text { The choice of the approach to elaboration } \\
\text { of thestandards (field or principle-based) }\end{array}$ & Discussion within the whole workgroup \\
\hline $\begin{array}{l}\text { Developing Ukrainian standards on the basis } \\
\text { of TESOL standards }\end{array}$ & $\begin{array}{l}\text { Preparing a draft in subgroups. } \\
\text { Discussion within the whole workgroup }\end{array}$ \\
\hline Developing a system of standards' evaluation & $\begin{array}{l}\text { Work in subgroups. } \\
\text { Discussion within the whole workgroup }\end{array}$ \\
\hline Implementation (approbation) of the standards & $\begin{array}{l}\text { Combination of standards with training } \\
\text { programs (curricula, syllabi, disciplines) }\end{array}$ \\
\hline $\begin{array}{l}\text { Discussion of the results, formulation } \\
\text { of conclusions, further approbation }\end{array}$ & $\begin{array}{l}\text { Discussion and work within the whole } \\
\text { workgroup }\end{array}$ \\
\hline
\end{tabular}

In the result of the workgroup activities, there have been formulated the standards, presented in Table 5 .

Table 5

Field standards of foreign language teachers' professional training, elaborated by the workgroup

\begin{tabular}{|c|l|}
\hline Fields & \multicolumn{1}{c|}{ Standards } \\
\hline Language & $\begin{array}{l}\text { 1. Language as a system. } \\
\text { 2. Languagelearninganditsupgrading. } \\
\text { 3. Use (practicing) of the language }\end{array}$ \\
\hline Culture & $\begin{array}{l}\text { 1. Culture and its influence onto the students' learning. } \\
\text { 2. Comparative analysis of the target country culture and of the native one }\end{array}$ \\
\hline $\begin{array}{c}\text { Planning, } \\
\text { and control of the } \\
\text { learning process }\end{array}$ & $\begin{array}{l}\text { 1. Planning of the foreign language learning on the basis of standards. } \\
\text { 2. Implementation and control of the foreign language learning on the } \\
\text { 3. Effective use of technologies and resources in foreign language learning }\end{array}$ \\
\hline Assessment & $\begin{array}{l}\text { 1. General principles of assessment system. } \\
\text { 2. Current assessment of future foreign language teachers concerning } \\
\text { language knowledge. } \\
\text { 3. Assessment of the future teachers' language level (advanced/proficient) }\end{array}$ \\
\hline Professionalism & $\begin{array}{l}\text { 1. Professional formation of future foreign language teachers. } \\
\text { 2. Teachers' professional development. } \\
\text { 3. Professional cooperation of all the stakeholders }\end{array}$ \\
\hline
\end{tabular}

For the standard "Language as a system" the workgroup has developed performance indicators, presented in Table 6. 
Performance indicators for future English language teachers according to the standard "Language as a system"

\begin{tabular}{|l|l|}
\hline \multicolumn{1}{|c|}{ Performance indicator } & \multicolumn{1}{|c|}{ Indicators of correspondence to the standard } \\
\hline $\begin{array}{l}\text { A. Knowledge of the components } \\
\text { of the language and the language } \\
\text { as an integrative system }\end{array}$ & $\begin{array}{l}\text { Teachers use components of a language and language } \\
\text { as an integrative system to teach a foreign language }\end{array}$ \\
\hline \multicolumn{1}{|c|}{ Performance indicator } & \multicolumn{1}{|c|}{ Indicators of correspondence to the standard } \\
\hline $\begin{array}{l}\text { B. Using knowledge of phonology, } \\
\text { morphology, syntax, semantics, } \\
\text { pragmatics to help students with } \\
\text { the development of speaking, reading, } \\
\text { writing in English. }\end{array}$ & $\begin{array}{l}\text { Teachers apply knowledge of phonology, morphology, syntax, } \\
\text { semantics and pragmatics development to define aspects of } \\
\text { English which present difficulties for learning, and define } \\
\text { how they can positively influence the learning of these } \\
\text { language aspects by learners. Teachers help learners to } \\
\text { identify, use, master sound system of English and other } \\
\text { communicative skills, thus encouraging the development of } \\
\text { speaking skills. } \\
\text { Teachers teach syntactic structures which are necessary to } \\
\text { learners for effective social and educational communication. } \\
\text { Teachers incorporate different learning technologies to help } \\
\text { learners with the development of literacy skills. } \\
\text { Teachers incorporate different learning technologies to help } \\
\text { learners with understanding and appropriate use of } \\
\text { vocabulary in oral and written forms. } \\
\text { Teachers provide learners with timely help and sufficient } \\
\text { contextual practice with idioms, set expressions, phrasal } \\
\text { verbs, etc. } \\
\text { Teachers work out contextualized learning with the use of } \\
\text { formal and informal language to help learners with the use } \\
\text { and mastering a language with different purposes }\end{array}$ \\
\hline $\begin{array}{l}\text { C. Knowledge of discursive structures, } \\
\text { which take place in studying } \\
\text { English as a foreign language. }\end{array}$ & $\begin{array}{l}\text { Teachers use different strategies to help learners master } \\
\text { discursive structures, peculiartooral and written forms of } \\
\text { English }\end{array}$ \\
\hline $\begin{array}{l}\text { D. Demonstration of proficiency } \\
\text { learners a good example of language } \\
\text { proficiency (being a role model) }\end{array}$ & $\begin{array}{l}\text { Teachers demonstrate proficiency in all aspects of English } \\
\text { knglish }\end{array}$ \\
\hline
\end{tabular}

\section{CONCLUSIONS}

After elaboration of the standards and indicators of teachers' performance there has been chosen a group of fifth year students - future teachers of English in Secondary Education. English Language and Literature" specialty whose correspondence to the standards has been checked. A questionnaire form was developed to get a feedback from the students themselves and the lecturers who performed their training to estimate their attitude to standards and correspondence to them. The questionnaire included the following questions to students:

- Is this standard necessary, important?

- Is it clearly formulated?

- Can it be estimated? 
sciendo Порівняльна професійна педагогіка 8(3)/2018

Comparative Professional Pedagogy 8(3)/2018

- Do you consider yourself being able to correspond to all the performance indicators and if not, why?

Teachers had to answer students' questions, as well as to say whether the standards were completely covered by syllabus/curriculum, whether standards covered the whole content of professional training and if not, what should be taken into account, whether it was easy to estimate the correspondence of future teachers to the standards, whether future teachers understood standards and how they would be assessed on their basis, whether standards stipulated future foreign language teachers knowledge and abilities.

The questionnaire forms presupposed obligatory commented answers. The conducted questionnaire testifies that students (19 in total) consider standards to be necessary, important, clearly formulated, but the majority consider the content of education as not corresponding to the standards, and they consider standards not quite clearly evaluated. Only 9 students considered themselves corresponding to all the performance indicators (on the basis of the approbated standard "Language as a system").

Lecturers defined that the biggest problem was absence of a single definite system for estimation of students' correspondence to the standards (performance indicators provide only superficial estimation). It has to demonstrate whether future teachers, who completed training program according to these standards, correspond to them and can teach by themselves. Such estimation stipulates the availability of a portfolio (with lessons plans, demonstration lesson, self-assessment, etc.). One more problem is caused by the fact that existing syllabi and curricula don't cover all the aspects presupposed by the standards. Thus, there arises a necessity to adjust existing teacher training programs to elaborated standards.

But still it is too early to talk about productivity and efficiency of approbation, because the complete implementation of the standards needs approbation throughout the complete foreign language teachers' training program that is 4-6 years (depending on the degree - Bachelor or Master).

Still, at this stage of our research it is quite clear that the main difficulties of standards implementation are caused by the necessity to elaborate a definite system for assessing the correspondence to the standards and the adjustment of existing training programs to the standards. One of the possible solutions to the problem is involvement of stakeholders of different levels to elaboration of the standards (from future teachers to representatives of Ministry of Education). Practical implementation of this issue is the prospect of our further research in the area.

\section{REFERENCES}

1. Arter, J., \& McTighe, J. (2001). Scoring rubrics in the classroom: Using performance criteria for assessing and improving student performance. Thousand Oaks, CA: Corwin Press.

2. Burke, K. (Ed.). (2011). From standards to rubrics in 6 steps (3rd ed.). Thousand Oaks, CA: Corwin Press.

3. Canagarajah, A. S., \& Wurr, A. J. (2011). Multilingual communication and language acquisition: New research directions. The Reading Matrix, 11 (1), 1-15.

4. Council of Europe. (2001). Common European framework of reference for languages: Learning, teaching, assessment. Cambridge, United Kingdom: Cambridge University Press.

5. Darling-Hammond, L. (2017). Teacher Education Around the World: What Can We Learn from International Practice? European Journal of Teacher Education, 40 (3), 291-309. 
sciendo Порівняльна професійна педагогіка 8(3)/2018 Comparative Professional Pedagogy 8(3)/2018

6. Doiz, A., Lasagabaster, D., \& Sierra J., M. (2011). Internationalization, multilinguism and English-Medium Instruction. World Englishes, 30, 345-359.

7. Farrell, T. S. C. (2014). Reflective practice in ESL teacher development groups: From practices to principles. New York, NY: Palgrave Macmillan.

8. Kuhlman, N., Kneževič. (2013). The TESOL Guidelines for Developing EFL Professional Teaching Standards. TESOL International Association, 2013. Retrieved from: https://www.tesol.org/docs/default-source/pdf/the-tesol-guidelines-for-developing-eflstandards.pdf?sfvrsn $=0$.

9. Kuhlman, N. (2010). Developing foreign language teacher standards in Uruguay. GIST Education and Learning Research Journal, 4 (1), 107-126.

10. Liyanage, I., Walker, T., \& Singh, P. (2015). TESOL professional standards in the "Asian century": dilemmas facing Australian TESOL teacher education. Asia Pacific Journal of Education, 35 (4), 485-497.

11. Mahboob, A., \& Tilakaratna, N. (2012). Toward a principles-based approach for English language teaching policies and practices. White paper. Alexandria, VA: TESOL International Association.

12. National Council for Accreditation of Teacher Education. (2010, November). Transforming teacher education through clinical practice: A national strategy to prepare effective teachers. Retrieved from http://centralsquarefoundation.org/edresource/ transforming-teacher-education-through-clinical-practice-a-national-strategy-to-prepare-

effective-teachers/.

13. Richards, J. (2011). Competence and performance in language teaching. Cambridge, United Kingdom: Cambridge University Press.

14. Richards, J. (2017). Teaching English through English: Proficiency, Pedagogy and Performance. RELC Journal, 48, 7-30.

15. Staehr Fenner, D., \& Kuhlman, N. (2012). Preparing effective teachers of English language learners. Alexandria, VA: TESOL International Association.

16. Stevens, D., \& Levi, A. (2005). Introduction to rubrics: an assessment tool to save grading time, convey effective feedback, and promote student learning. Sterling, VA: Stylus.

17. TESOL International Association. (2007). Position statement on the role of teacher's associations in education policy and planning. Retrieved from http://www.tesol.org/docs/pdf/10040.pdf?sfvrsn=2.

18. TESOL International Association. (2010). TESOL P-12 professional teaching standards (2nd ed.). Alexandria, VA: Author.

19. TESOL International Association. (2013). Implementing the common core state standards for ESL. The changing role of the ESL teacher. Alexandria, VA: Author.

20. TESOL International Association. (2017). Draft 2017 TESOL standards for P-12 teacher education programs. Retrieved from: https://www.tesol.org/docs/defaultsource/advocacy/tesol_standards-p12-teacheredprograms-public-draft.pdf?sfvrsn=0 